Boston University School of Law

Scholarly Commons at Boston University School of Law

Faculty Scholarship

2-26-2015

\title{
Testimony Before the House Committee on Energy and Commerce, Hearing on Patent Demand Letter Practices and Solutions
}

Paul Gugliuzza

Boston University School of Law

Follow this and additional works at: https://scholarship.law.bu.edu/faculty_scholarship

Part of the Intellectual Property Law Commons

\section{Recommended Citation}

Paul Gugliuzza, Testimony Before the House Committee on Energy and Commerce, Hearing on Patent Demand Letter Practices and Solutions, No. 15-07 Boston University School of Law, Public Law Research Paper (2015).

Available at: https://scholarship.law.bu.edu/faculty_scholarship/805

This Article is brought to you for free and open access by Scholarly Commons at Boston University School of Law. It has been accepted for inclusion in Faculty Scholarship by an authorized administrator of Scholarly Commons at Boston University School of Law. For more information, please contact lawlessa@bu.edu. 


\section{BU School of Law}

\section{TESTIMONY BEFORE THE HOUSE COMMITTEE ON ENERGY AND COMMERCE, HEARING ON PATENT DEMAND LETTER PRACTICES AND SOlUTIONS}

Boston University School of Law Public Law \& Legal Theory Paper No. 15-07 (March 4, 2015)

\section{Paul R. Gugliuzza}

Boston University School of Law

This paper can be downloaded without charge at:

http://www.bu.edu/law/faculty/scholarship/workingpapers/2015.html 
Testimony Before the House Committee on Energy and Commerce, Hearing on Patent Demand Letter Practices and Solutions

\author{
Paul R. Gugliuzza \\ Associate Professor of Law \\ Boston University School of Law \\ Committee on Energy and Commerce \\ Subcommittee on Commerce, Manufacturing, and Trade \\ U.S. House of Representatives \\ Hearing: “Update: Patent Demand Letter Practices and Solutions"
}

February 26, 2015 


\section{Introduction}

Chairman Burgess, Ranking Member Schakowsky, and Members of the

Subcommittee: Thank you for inviting me to testify. My name is Paul Gugliuzza. I am an associate professor of law at Boston University School of Law. I testify in my individual capacity, not representing my institution.

My research focuses on patent law and patent litigation. Most relevant to this hearing, I have spent the past two years studying the issue of patent demand letters, focusing in particular on efforts by both state governments and the federal government to address the problem of unfair and deceptive conduct in patent enforcement. ${ }^{1}$

To briefly summarize my conclusions: A small number of patent holders, often called "bottom feeder" patent trolls, have been abusing the patent system. These patent holders blanket the country with thousands of letters demanding that the recipients purchase a license for a few thousand dollars or else face an infringement suit. The letters are usually sent to small businesses and nonprofits that do not have the resources to defend against claims of patent infringement. And the letters often contain false or misleading statements designed to scare the recipient into purchasing a license without investigating the merits of the allegations. In response to this troubling behavior, legislatures in eighteen states have recently adopted statutes that, generally speaking, outlaw bad faith assertions of patent infringement.

${ }^{1}$ For an in-depth discussion of this research, see Paul R. Gugliuzza, Patent Trolls and Preemption, 101 VA. L. REV. (forthcoming 2015), available at http://ssrn.com/abstract=2539280. 
These statutes, however, may be unconstitutional. The U.S. Court of Appeals for the Federal Circuit, which has exclusive jurisdiction over appeals in patent cases in the federal courts, has held that patent holders are immune from civil claims challenging acts of patent enforcement unless the patent holder knew that its infringement allegations were objectively baseless. This rule could provide patent holders with nearly absolute immunity from liability under the new statutes. In fact, as I discuss in more detail below, the rule has already immunized two notorious trolls, Innovatio IP Ventures and MPHJ Technology Investments, from legal challenges to their enforcement campaigns under state consumer protection and deceptive trade practices laws.

Although the Federal Circuit has sometimes called this immunity rule a matter of the federal Patent Act's "preemption" of state law, the rule could also limit the ability of the federal government to regulate patent enforcement behavior. This is because the Federal Circuit's decisions are not grounded in the Constitution's Supremacy Clause, which is the usual source of preemption doctrine, but in the First Amendment right to petition the government. Unlike the Supremacy Clause, the First Amendment limits the power of the federal government, not just state governments. Accordingly, patent holders may also be able to invoke this immunity to thwart federal initiatives to fight patent trolls - including any legislation this Committee might consider. 
To be clear, no court has yet addressed the constitutionality of the new state statutes. Moreover, as I discuss in more detail below, there is a strong argument that the Federal Circuit's immunity doctrine is wrong as a matter of law, policy, and historical practice. So, it is entirely possible that the Federal Circuit could revise its immunity doctrine to accommodate greater regulation of patent enforcement conduct. Also, to the extent that cases challenging patent enforcement conduct proceed in state court, those state courts are not required to follow the Federal Circuit's expansive immunity doctrine.

This hearing provides a welcome occasion to discuss the innovative steps that state governments have taken to combat unfair and deceptive patent enforcement. Any bill advanced by this Committee should, in my view, capitalize on the respective strengths of state governments and the federal government in this area. The strengths of state governments include: (1) the quantity of law enforcement resources that could be provided by dozens of states' attorneys general offices cooperating to fight abusive patent enforcement, (2) the accessibility of state governments to the small businesses, nonprofits, and local governments likely to be targeted by deceptive campaigns of patent enforcement, and (3) the ability of targeted organizations to act as private attorneys general under both the new state statutes and other state consumer protection and deceptive trade practices laws. By contrast, federal legislation on patent demand letters would provide the obvious benefits of legal uniformity and greater predictability 
for patent holders about whether or not their enforcement actions are legal. In addition, as I explain in more detail below, federal legislation could clarify difficult jurisdictional issues that currently arise in cases challenging the lawfulness of patent enforcement conduct.

If this Committee determines that federal legislation is warranted, that legislation should, in my view, specifically condemn "bad faith" assertions of patent infringement. Until the Federal Circuit adopted its "objective baselessness" requirement, courts had applied a bad faith standard for nearly a century, striking an appropriate balance between the goals of punishing extortionate schemes of patent enforcement and respecting patent holders' rights to make legitimate allegations of infringement.

\section{The Problem: Bottom Feeder Patent Trolls}

In the past decade, scholars and policymakers have fixated on "patent trolls" or, less pejoratively, nonpracticing entities (NPEs). NPEs are often criticized because they do not manufacture products or provide services. Instead, they exist primarily to enforce patents. But the NPE business model is not inherently nefarious. Research universities, for example, usually cannot commercialize the patents obtained by their faculty, so they license the technology to others and sometimes sue for infringement. NPEs can also help monetize inventions by those who cannot afford to assert their patents in litigation, such as individual inventors and start-up companies. 
In the past few years, however, a species of "bottom feeder" trolls has emerged.

These trolls send out hundreds or thousands of demand letters at one time, relying on the high cost of patent litigation in the hope of eliciting a nuisance-value settlement, that is, a settlement payment that is less that the amount it would cost to investigate the infringement allegations. ${ }^{2}$ Bottom feeders target small businesses, nonprofits, and even local governments, knowing that those organizations are unfamiliar with patent litigation and likely cannot afford to defend against infringement claims. ${ }^{3}$

One well-known bottom-feeder troll is the company MPHJ Technology Investments. In 2012 and 2013, MPHJ sent letters to over 16,000 small businesses throughout the United States. ${ }^{4}$ The letters accused the recipients of infringing a patent that covers the use of an office scanner to send documents via email. MPHJ demanded that each recipient purchase a license for about $\$ 1200$ per employee or else face an infringement suit in federal court.

Another bottom feeder who has engaged in a mass enforcement campaign is Innovatio IP Ventures. Beginning in 2011, Innovatio sent letters to over 8,000 businesses throughout the United States, including bakeries, hotels, and restaurants, claiming that

\footnotetext{
2 See Mark A. Lemley \& A. Douglas Melamed, Missing the Forest for the Trolls, 113 Colum. L. Rev.
} 2117, 2126 (2013).

${ }^{3}$ See Colleen Chien \& Edward Reines, Why Technology Customers Are Being Sued En Masse for Patent Infringement and What Can Be Done, 49 WAKE FOREST L. ReV. 235, 235 (2014).

${ }^{4}$ Samples of these letters can be found in a complaint for unfair competition filed by the Federal Trade Commission, In re MPHJ Tech. Investments, LLC, No. 142-3003 (Nov. 6, 2014), available at http://www.ftc.gov/enforcement/cases-proceedings/142-3003/mphj-technology-investments-llc-matter, archived at http://perma.cc/T93Z-SVJL. 
those businesses infringed its patents by providing customers with wireless Internet access. ${ }^{5}$ Innovatio demanded that the recipients purchase licenses for about $\$ 2500$ each or risk being sued for patent infringement.

The demand letters sent in these mass enforcement campaigns are often rife with false or deceptive statements. MPHJ, for instance, obscured its identity by sending letters through eighty-one shell companies with nonsensical names such as DolVol, GanPan, and JitNom. To intimidate recipients into quickly purchasing a license, MPHJ threatened to sue if the recipient did not respond within two weeks. But, in fact, MPHJ never sued any of the targets of its mass enforcement campaign. Likewise, both Innovatio and MPHJ falsely claimed that many other businesses had already purchased licenses to their patents.

\section{State Governments Respond}

State legislatures across the country have responded to these troublesome patent enforcement tactics. In the past two years, legislatures in eighteen states have adopted statutes outlawing false or bad faith assertions of patent infringement, and nearly a dozen additional states are currently considering similar legislation. ${ }^{6}$ The most popular model for state legislation is a statute first adopted in Vermont, which, in May 2013

${ }^{5}$ See In re Innovatio IP Ventures, LLC Patent Litig., 921 F. Supp. 2d 903, 907 (N.D. Ill. 2013).

${ }^{6}$ For a regularly updated list of state legislative actions, see Patent Progress's Guide to State Patent Legislation, PATENT PROGRESS, http://www.patentprogress.org/patent-progresss-guide-state-patentlegislation (last visited Feb. 22, 2015), archived at http://perma.cc/4VXD-DF6E. 
became the first state to adopt legislation specifically regulating patent enforcement. ${ }^{7}$

Since then, thirteen other states have adopted statutes modeled after Vermont's, with some minor variations. ${ }^{8}$ And the Council of State Governments included the Vermont statute in its most recent volume of suggested state legislation. ${ }^{9}$

The core provision of the Vermont statute states, simply: "A person shall not make a bad faith assertion of patent infringement."10 The statute then lists several factors that courts "may consider ... as evidence that a person has made a bad faith assertion of patent infringement," including:

- The demand letter does not contain: the patent number, the name and address of the patent holder, or "factual allegations concerning the specific areas in which the target's products, services, and technology infringe the patent."

- The demand letter lacks the information noted above, the target requests the information, and the patent holder fails to provide the information "within a reasonable amount of time."

- The patent holder has previously filed or threatened to file lawsuits and those threats lacked the information noted above or were found by a court to be meritless.

- Prior to sending the demand letter, the patent holder did not conduct an analysis comparing the claims of the patent to the target's

7 Interestingly, the United Kingdom has recognized a civil claim for persons targeted with groundless threats of suit for patent infringement since 1883. For a discussion of this so-called "threats action," see U.K. LAW COMM'N, PATENTS, TRAdE MARK AND DESign RightS: Groundless Threats (Apr. 2014).

8 The states that have followed Vermont's model include Alabama, Georgia, Idaho, Louisiana, Maine, Maryland, Missouri, New Hampshire, North Carolina, Oregon, South Dakota, Utah, and Virginia.

${ }^{9}$ See Suggested State Legislation, COUNCIL OF STATE GOVERNMENTS, http://www.csg.org/ programs/policyprograms/SSL.aspx (last visited Feb. 22, 2015), archived at http://perma.cc/3U5Y-P876.

${ }^{10}$ VT. STAT. ANN., tit. 9, § 4197(a). 
products, services, or technology, "or such an analysis was done but does not identify specific areas in which the products, services, and technology are covered by the claims in the patent."

- The demand letter demands payment of a license or a response "within an unreasonably short period of time."

- The patent holder "offers to license the patent for an amount that is not based on a reasonable estimate of the value of the license."

- "The claim or assertion of patent infringement is meritless, and the person knew, or should have known, that the claim or assertion is meritless."

- "The claim or assertion of patent infringement is deceptive." ${ }^{11}$

In addition to the Vermont model, two other types of state patent-demand-letter statutes exist. First, Wisconsin has adopted a statute that outlines in detail the information that a demand letter must include, such as the name of the patent owner, an identification of each patent claim being asserted, an identification of the allegedly infringing product or service, and "[f]actual allegations and an analysis setting forth in detail" the patent holder's theory of infringement. ${ }^{12}$ The Wisconsin statute can be violated in two ways: First, if the letter lacks any of the required information, the target may notify the sender that the letter is incomplete. If the sender does not provide the missing information within thirty days, the sender violates the statute..$^{13}$ Second, a

${ }^{11} I d$. 4197(b). The statute also lists several factors suggesting that an infringement assertion was not made in bad faith, many of which are simply the opposite of the factors listed in the text. See id. $\S$ 4197(c).

12 WIS. STAT. § 100.197(2)(a).

${ }^{13} \mathrm{Id} . \S 100.197(2)(\mathrm{c})$. 
demand letter violates the Wisconsin statute if it "contain[s] false, misleading, or deceptive information."14

A third and final model of state legislation has been adopted in Illinois, Oklahoma, and Tennessee. Rather than prohibiting false or bad faith assertions of patent infringement, these statutes outline specific acts or omissions that violate the statute, such as "falsely stat[ing] that litigation has been filed" against the recipient, seeking compensation for infringement of a patent that has been held invalid or has expired, or failing to include "factual allegations concerning the specific areas in which the [recipient's] products ... infringe[] the patent."15 The statutes also make clear that it is not unlawful to notify others of or to seek compensation for patent infringement, so long as the patent owner "is not acting in bad faith."16

All of the state statutes provide for enforcement by state officials, such as the state attorney general. And most of the statutes create a private right of action for the targets of unlawful infringement assertions. The remedies available in those private suits include equitable relief, compensatory damages, treble damages, and attorneys' fees.

In addition to these new state statutes, attorneys general in several states have begun to use their powers under consumer protection and deceptive trade practices

\footnotetext{
${ }^{14}$ Id. $\S 100.197(2)(\mathrm{b})$.

${ }^{15}$ E.g., OKLA. STAT. tit. 23, § 112(A).

${ }^{16}$ E.g., id. $\S 112(\mathrm{~B})$.
} 
laws to fight bottom-feeder trolls. Vermont's attorney general, for instance, sued MPHJ in May 2013, alleging that MPHJ's demand letters violated Vermont's general consumer protection statute. ${ }^{17}$ (The suit was filed two weeks before Vermont's demand letter statute took effect.) Around the same time, the attorney general of Nebraska began an investigation into whether a law firm representing MPHJ and Activision TV, another NPE, had violated Nebraska's consumer protection and deceptive trade practices statutes. ${ }^{18}$ And the attorneys general of New York and Minnesota have negotiated agreements with MPHJ to curb its enforcement activity. ${ }^{19}$

\section{Constitutional Limits on State Governments and the Federal Government}

These new state statutes and state law enforcement actions challenge the conventional wisdom that patent law is the domain of the federal government alone.

Indeed, the website of the U.S. Patent and Trademark Office now counsels persons who receive demand letters that are "deceptive, predatory, or in bad faith," to, among other things, "fil[e] a complaint with your state attorney general's office." ${ }^{20}$ Doctrines of

${ }^{17}$ See Consumer Protection Complaint at 1-8, Vermont v. MPHJ Tech. Investments, LLC, No. 2825-13wncv (Vt. Super. Ct. May 8, 2013), available at http://www.atg.state.vt.us/assets/files/ Vermont\%20v\%20MPHJ\%20Technologies\%20Complaint.pdf, archived at http://perma.cc/93X8-G6NS.

${ }^{18}$ See Letter from Jon Bruning, Attorney Gen. of Neb., to M. Brett Johnson, Partner, Farney Daniels LLP (July 18, 2013), available at http://ipwatchdogs.com/cases/NE-cease-desist.pdf, archived at http://perma.cc/FQ9Y-WSGV.

${ }^{19}$ See Investigation by Eric T. Schneiderman, Att'y Gen. of the State of New York, of MPHJ Tech. Investments, LLC, Assurance No. 14-015, at 12-19 (Jan. 13, 2014); Julie Samuels, Minnesota: Patent Trolls are Not Welcome Here (Aug. 21, 2013), ELEC. FRONTIER FOUND., https://www.eff.org/deeplinks/2013/08/ minnesota-patent-trolls-are-not-welcome-here, archived at http://perma.cc/D2P7-4VGD.

${ }^{20}$ I Got a Letter . . , , U.S. PATENT \& TRADEMARK OFF., http://www.uspto.gov/patents/litigation/ I_got_a_letter.jsp (last visited Feb. 22, 2015), archived at http://perma.cc/Y3RL-S3D3. 
federal constitutional law developed by the Federal Circuit, however, may invalidate the new state statutes and limit the enforcement authority of state officials. Moreoverand most importantly for the purpose of this hearing - those same doctrines may also limit the legislative power of Congress and the enforcement authority of the federal government.

\section{A. Judicially Created Immunity for Patent Holders}

For decades, persons accused of patent infringement have tried to assert civil claims against overzealous patent holders. Those claims are sometimes grounded in state law (for example, claims for unfair competition or for tortious interference with business relations) and other times grounded in federal law (for example, claims for unfair competition under the Lanham Act or for violations of the civil RICO statute). The Federal Circuit, however, has held that patent holders are mostly immune from civil liability for their enforcement behavior. According to the Federal Circuit, to strip a patent holder of this immunity, the plaintiff must prove not only the elements of its state or federal claim, it must also prove, by clear and convincing evidence, (1) that the patent holder's infringement allegations were "objectively baseless," meaning that no reasonable litigant could have expected to succeed, and (2) that the patent holder made its infringement allegations with knowledge of their inaccuracy or with reckless disregard for their accuracy. ${ }^{21}$

${ }^{21}$ Globetrotter Software, Inc. v. Elan Computer Grp., Inc., 362 F.3d 1367, 1377 (Fed. Cir. 2004). 
Although no court has yet applied this standard to the new state statutes, it seems to ensure that most tactics employed by bottom-feeder trolls will remain legal. To begin with, the rule requires a plaintiff to show that the patent holder's infringement allegations were objectively baseless. ${ }^{22}$ Accordingly, false statements about matters peripheral to the infringement claims, such as misrepresentations about how many other persons have purchased licenses to the patents, will not strip a patent holder of immunity. ${ }^{23}$

Moreover, it is very difficult to prove that infringement allegations were objectively baseless. The issue of infringement often turns on the judge's interpretation of the patent's claims. Those decisions are notoriously unpredictable, ${ }^{24}$ making it hard to say that any given infringement allegation was so unlikely to succeed that it was objectively baseless. Also, an accused infringer who seeks to show that a patent is invalid must prove invalidity by clear and convincing evidence. ${ }^{25}$ Thus, even if a patent probably does not satisfy validity requirements such as novelty and nonobviousness, this high burden of proof could still give the patent holder a reasonable hope of success.

${ }^{22}$ See id. ("A plaintiff claiming that a patent holder has engaged in wrongful conduct by asserting claims of patent infringement must establish that the claims of infringement were objectively baseless." (emphasis added)).

${ }^{23}$ See, e.g., In re Innovatio IP Ventures, LLC Patent Litig., 921 F. Supp. 2d 903, 922 (N.D. Ill. 2013) (dismissing claims challenging patent enforcement conduct where the alleged false statements "[were] all peripheral to the question of infringement"); Activision TV, Inc. v. Bruning, No. 8:13-CV-215, slip op. at 13 (D. Neb. Sept. 2, 2014) (applying Federal Circuit law, noting that "the crucial issues to establish objective[] baselessness involve validity and infringement").

${ }^{24}$ See Dan L. Burk \& Mark A. Lemley, Fence Posts or Sign Posts? Rethinking Patent Claim Construction, 157 U. PA. L. REV. 1743, 1744-46 (2009).

${ }^{25}$ See Microsoft Corp. v. i4i Ltd. P'ship, 131 S. Ct. 2238, 2242 (2011). 
That is sufficient under Federal Circuit law to immunize the patent holder from liability. In my research, I have conducted an extensive survey of Federal Circuit cases applying this immunity rule, and I have found that it is extremely rare for a plaintiff to prevail on a claim challenging patent enforcement conduct. ${ }^{26}$

Most disturbingly, two federal district courts have relied on the Federal Circuit's immunity doctrine to shelter Innovatio and MPHJ. After Innovatio began its enforcement campaign against users of wireless Internet routers, the manufacturers of the routers (Cisco, Motorola, and Netgear) sued Innovatio, asserting a claim under the federal RICO statute and several claims under California state law. ${ }^{27}$ The complaint alleged that Innovatio had made numerous false statements in its letters, including statements that it had "successfully licensed thousands of business locations under the ... patents" and that "the validity of many claims of the ... patents ha[d] been confirmed by both the Federal Circuit and the United States Patent Office, via both judicial and re-examination proceedings." ${ }^{28}$ On Innovatio's motion to dismiss, the court

${ }^{26}$ By my count, since 2004, the Federal Circuit has barred the plaintiff's claim in all but one case raising an immunity issue. See Matthews Int'l Corp. v. Biosafe Eng' g, LLC, 695 F.3d 1322, 1332 (Fed. Cir. 2012); Contech Stormwater Solutions, Inc. v. Baysaver Techs., Inc., 310 F. App'x 404, 409 (Fed. Cir. 2009); 800 Adept, Inc. v. Murex Sec., Ltd., 539 F.3d 1354, 1372 (Fed. Cir. 2008); Judkins v. HT Window Fashion Corp., 529 F.3d 1334, 1339 (Fed. Cir. 2008); Dominant Semiconductors Sdn. Bhd. v. OSRAM GmbH, 524 F.3d 1254, 1264 (Fed. Cir. 2008); GP Indus., Inc. v. Eran Indus., Inc., 500 F.3d 1369, 1375-76 (Fed. Cir. 2007); Serio-US Indus., Inc. v. Plastic Recovery Techs. Corp., 459 F.3d 1311, 1321 (Fed. Cir. 2006). But see Breckenridge Pharm., Inc. v. Metabolite Labs., Inc., 444 F.3d 1356, 1369 (Fed. Cir. 2006) (reversing summary judgment, holding that "the question of whether [the patent holder's] statements ... were 'objectively baseless' is genuinely disputed").

27 Innovatio, 921 F. Supp. $2 \mathrm{~d}$ at 906.

${ }^{28} \mathrm{Id}$. at $920-21$. 
accepted the plaintiffs' allegations as true but still dismissed the complaint. ${ }^{29}$ Although the plaintiffs alleged that Innovatio had lied in its demand letters, the court reasoned that Innovatio was immune from civil liability because the plaintiffs did not plead that Innovatio's infringement claims were objectively baseless, ${ }^{30}$ as the Federal Circuit requires.

Likewise, a federal district court in Nebraska enjoined that state's attorney general from pursuing a state-law case against MPHJ because the attorney general did not allege that MPHJ's theories of validity and infringement were objectively baseless. ${ }^{31}$ The attorney general argued that MPHJ had made "false and misleading representations" in its demand letters, such as statements that many businesses had already purchased a license and that it intended to file suit against recipients who did not purchase a license. ${ }^{32}$ But the court held that to strip MPHJ of immunity, the attorney general had to show that MPHJ's theories of validity and infringement were objectively baseless, which the attorney general had not done. ${ }^{33}$

${ }^{29}$ Id. at 922.

${ }^{30} \mathrm{Id}$. at 921.

${ }^{31}$ See Activision TV, Inc. v. Bruning, No. 8:13-CV-215, slip op. at 13-14 (D. Neb. Sept. 2, 2014).

32 See id. at 13.

${ }^{33} \mathrm{Id}$. at $11,13-14$. 
In short, it is not hyperbole to say that, under the Federal Circuit's immunity doctrine, patent holders have a "legal right to lie" in their demand letters. ${ }^{34}$ It is these (legally protected) lies that are motivating increased interest by state governments in regulating patent enforcement.

\section{B. Limits on the Power of the Federal Government?}

Courts and commentators sometimes call the immunity enjoyed by patent holders a matter of "preemption" because it is most frequently invoked when an alleged infringer relies on state law to challenge a patent holder's behavior in enforcing a federal patent. ${ }^{35}$ The term "preemption" suggests that the source of the immunity doctrine is the Constitution's Supremacy Clause, which limits the power of state governments, not the federal government. In more recent cases, however, the Federal Circuit has made clear that its immunity doctrine stems not from the Supremacy Clause alone, but from the First Amendment, ${ }^{36}$ which does limit the power of the federal government. As a consequence, the immunity doctrine seems to apply equally to state governments and the federal government, and patent holders may be able to claim

${ }^{34}$ Steven Seidenberg, Infringe Benefits: Patent Trolls Getting First Amendment Protection, A.B.A. J., May 2014, http://www.abajournal.com/magazine/article/patent_trolls_are_getting_first_amendment_ protection_for_demand_letters, archived at http://perma.cc/LQ82-JSV5.

${ }^{35}$ See, e.g., Hunter Douglas, Inc. v. Harmonic Design, Inc., 153 F.3d 1318, 1338 (Fed. Cir. 1998); David Lee Johnson, Note, Facing Down the Trolls: States Stumble on the Bridge to Patent-Assertion Regulation, 71 WASH. \& LEE L. REV. 2023, 2027 (2014).

${ }^{36}$ Globetrotter Software, Inc. v. Elan Computer Grp., Inc., 362 F.3d 1367, 1377 (Fed. Cir. 2004) ("Our decision to permit state-law tort liability for only objectively baseless allegations of infringement rests on both federal preemption and the First Amendment."). 
immunity from federal initiatives to fight patent trolls, too-including any legislation this Committee might consider adopting.

\section{An Argument Against Broad Immunity}

It is not, however, a foregone conclusion that patent holders will be able to claim broad immunity from government efforts to regulate unfair or deceptive demand letters. To the extent that challenges to patent enforcement conduct proceed in state court, such as the Vermont attorney general's suit against MPHJ, those courts could develop a different, narrower immunity rule than the Federal Circuit has developed, for state courts are not bound to follow Federal Circuit law. Indeed, there is a strong argument based on law, policy, and historical practice that the Federal Circuit has erred in granting patent holders such broad immunity for their enforcement conduct.

To begin with, the Federal Circuit has arguably misconstrued the relevant law. The Federal Circuit has derived its immunity test from the requirements imposed by the Supreme Court on plaintiffs who seek to inflict antitrust liability on defendants based on those defendants' pursuit of litigation. ${ }^{37}$ This doctrine, often called the NoerrPennington doctrine (or Noerr doctrine, for short), ${ }^{38}$ stems from the Supreme Court's interpretation of the federal antitrust statute, the Sherman Act, in the light of the First Amendment's Petition Clause, which protects "the right of the people ... to petition the

${ }^{37} \mathrm{Id}$. at 1375 .

38 The doctrine's name stems from the cases in which the Supreme Court first developed it. See E. R.R. Presidents Conf. v. Noerr Motor Freight, Inc., 365 U.S. 127 (1961); United Mine Workers of Am. v. Pennington, 381 U.S. 657 (1965). 
government for a redress of grievances." ${ }^{39}$ But the Federal Circuit's reliance on Noerr's view of the Petition Clause is a mistake: Letters sent from one private party to another, such as letters threatening patent infringement litigation, are simply not "petition[s]" to "the government" within the meaning of the First Amendment.

By looking to history, the Federal Circuit could better strike a balance between protecting patent holders from liability when they make legitimate allegations of infringement and punishing patent holders when they employ unfair or deceptive tactics. At the time the Federal Circuit was created in 1982, the lower federal courts had - for nearly a century - been addressing the precise question of when a patent holder may be held liable for its enforcement conduct. Those courts enjoined patent holders from making infringement assertions in bad faith-exactly the behavior that many of the new state statutes condemn. ${ }^{40}$ But the Federal Circuit has largely ignored that long line of decisions, instead demanding that anyone challenging patent enforcement conduct prove that the infringement allegations were objectively baseless.

Historically, the courts treated bad faith as a flexible standard with both subjective and objective components. ${ }^{41}$ Under this equity-based immunity standard-as opposed to the rigid "objective baselessness" test mandated by the Federal Circuit - the

\footnotetext{
${ }^{39}$ U.S. Const. amend. I.

40 See, e.g., Emack v. Kane, 34 Fed. 46, 50-51 (C.C.N.D. Ill. 1888).

${ }^{41}$ See Mark S. Bicks, Threatening to Sue for Patent Infringement: Unfair Competition and Antitrust Consequences, 59 J. PAT. OFF. SOC'Y 302, 303-04 (1977) (“The good faith involved refers to a state of mind and, in this context, means that the speaker sincerely and reasonably believes in the truth of his statements.").
} 
government could impose reasonable restrictions on patent enforcement, enjoining enforcement campaigns where, for instance, the patent holder threatened a large number of accused infringers ${ }^{42}$ or failed to follow its threats with actual lawsuits. ${ }^{43}$ At the same time, cases in which courts enjoined enforcement conduct under the traditional standard were usually egregious and often involved claims that were objectively weak on the merits. ${ }^{44}$ Accordingly, a good faith immunity standard - as opposed to the Federal Circuit's "objective baselessness" rule-would protect patent holders' ability to provide legitimate notice of their patent rights while offering the government some leeway to punish deceptive behavior.

\section{What Can Congress Do?}

If, as the Federal Circuit claims, broad immunity for patent holders is mandated by the First Amendment, it might appear as if there is little Congress can do to regulate demand letters. However, I believe Congress can still play an important role in this area. To begin with, this hearing can serve the important function of bringing a problematic line of cases to the attention of both the Federal Circuit and the Supreme Court. This Committee's discussion could encourage the Federal Circuit to reconsider its case law.

\footnotetext{
${ }^{42}$ E.g., Int'1 Indus. \& Devs., Inc. v. Farbach Chem. Co., 241 F.2d 246, 247-48 (6th Cir. 1957).

${ }^{43}$ E.g., Adriance, Platt \& Co. v. Nat'1 Harrow Co. 121 F. 827, 829-30 (2d Cir. 1903).

${ }^{44}$ E.g., Emack, 34 Fed. at 49.
} 
Such a response to the work of a congressional committee would not be unprecedented. Several scholars (including myself) have observed that the Federal Circuit keeps close watch when Congress considers amending patent law and have found numerous examples of the court revising its case law to align with proposed legislation. ${ }^{45}$ For instance, in the mid-to-late 2000s, Congress considered several bills to restrict plaintiffs' choice of venue in patent cases. While those bills were pending, the Federal Circuit-for the first time ever-ordered a district court to transfer a patent case to a more convenient venue. ${ }^{46}$ After that initial decision, the Federal Circuit issued several more opinions ordering transfer ${ }^{47}$ To date, the core venue statute remains unchanged. ${ }^{48}$

Likewise, during roughly the same time period, Congress was considering proposals to limit damages in patent cases. While those proposals were pending, the Federal Circuit issued several decisions increasing its scrutiny of damages awards. For instance, the court conducted a close review of the facts supporting a jury's royalty calculation, overturning a nearly $\$ 358$ million award against Microsoft as unsupported

${ }^{45}$ See Paul R. Gugliuzza, The Federal Circuit as a Federal Court, 54 WM. \& MARY. L. REv. 1791, 182728 (2013); see also Jonas Anderson, Congress as a Catalyst of Patent Reform at the Federal Circuit, 63 AM. U. L. REV. 961, 966-69 (2014).

${ }^{46}$ See In re TS Tech USA Corp., 551 F.3d 1315, 1321-22 (Fed. Cir. 2008); see also 28 U.S.C. § 1404(a) ("For the convenience of parties and witnesses, in the interest of justice, a district court may transfer any civil action to any other district or division where it might have been brought ...."). (2012).

47 See generally Paul R. Gugliuzza, The New Federal Circuit Mandamus, 45 IND. L. REV. 343, 346

$$
{ }^{48} \text { See } 28 \text { U.S.C. } \S 1400(b) \text {. }
$$


by the evidence. ${ }^{49}$ The court also rejected the much-maligned " 25 percent rule of thumb" as a starting point for the hypothetical negotiation used to calculate a reasonable royalty. ${ }^{50}$ Thus, the fact that the Committee is holding this hearing and considering legislation to regulate patent demand letters could spur the Federal Circuit to reconsider its immunity doctrine.

In addition, this hearing draws attention to the important efforts of state governments to combat abusive patent enforcement. The proliferation of state statutes and state law enforcement activities raises the question of whether, going forward, this problem is best solved through state-federal cooperation or whether patent law should remain the federal government's exclusive domain.

Congress could, if it so chooses, expressly preempt state law in this area pursuant to the Supremacy Clause. A single, federal statute governing patent enforcement has some obvious benefits: It would provide a uniform legal standard to govern all patent enforcement efforts undertaken anywhere in the country. A uniform legal standard should, in theory, allow patent holders to better predict whether their actions are lawful or not.

But the benefits of legal uniformity should not be overstated. Several scholars (myself included) have recently questioned whether uniformity is a sufficiently important policy goal in the patent system that it should outweigh the benefits of

${ }^{49}$ Lucent Techs., Inc. v. Gateway, Inc., 580 F.3d 1301, 1324-36 (Fed. Cir. 2009).

${ }^{50}$ Uniloc USA, Inc. v. Microsoft Corp., 632 F.3d 1292, 1315 (Fed. Cir. 2011). 
interjurisdictional dialogue and experimentation. ${ }^{51}$ It is likely no coincidence that, since states began adopting anti-troll statutes, the frequency of mass enforcement campaigns seems to be decreasing. State-by-state regulation in this area may have significant deterrence value: Rather than defending against, say, one investigation brought by the Federal Trade Commission, a patent holder might be forced to defend against multiple lawsuits in multiple states, brought by both private plaintiffs and state attorneys general.

State law enforcement agencies also provide substantial enforcement resources. The ability of dozens of states' attorneys general offices, joining together, to monitor and punish deceptive patent enforcement behavior likely dwarfs what the federal government could do. And state governments are more accessible than the federal government to those most likely to be targeted by bottom-feeder trolls: small businesses, nonprofits, and local governments. Vermont's pathmarking statute, for instance, was the product of a grassroots effort: businesses and non-profits in the state that had received demand letters from trolls approached their state legislators and attorney general and, together, they drafted Vermont's statute.

An approach to regulating demand letters that emphasizes the respective strengths of state governments and the federal government would be optimal. One

${ }^{51}$ See Paul R. Gugliuzza, Patent Law Federalism, 2014 WIS. L. Rev. 11, 48-51; Craig Allen Nard \& John F. Duffy, Rethinking Patent Law's Uniformity Principle, 101 NW. U. L. REV. 1619, 1623 (2007); Lisa Larrimore Ouellette, Patent Experimentalism, 101 VA. L. REV. (forthcoming 2015) (manuscript at 7-13), available at http://ssrn.com/abstract=2294774. 
important strength of federal regulation, which has not been widely discussed, is that it could provide certainty about which courts can hear cases involving unfair or deceptive patent demand letters. The federal district courts have exclusive subject-matter jurisdiction over cases "arising under" patent law,, 52 meaning that state courts cannot hear those cases. But difficult questions occur when a plaintiff asserts a state-law claim that implicates federal patent law, such as the Vermont attorney general's consumer protection lawsuit against MPHJ. MPHJ was able to delay that suit for nearly a year by arguing that the state had improperly filed the case in state court. ${ }^{53}$ If Congress were to enact a federal statute governing patent demand letters, cases involving claims under that statute would be-without question - subject to the federal courts' exclusive subject-matter jurisdiction.

A federal statute governing patent demand letters could also reduce uncertainty on matters of personal jurisdiction. The courts of a particular state may exercise jurisdiction over a defendant only if the defendant has "certain minimum contacts" with that state "such that the maintenance of the suit does not offend traditional notions of fair play and substantial justice." ${ }^{54}$ Typically, the personal jurisdiction of a federal court is the same as the jurisdiction of the courts of the state in which the federal court

5228 U.S.C. § 1338(a).

${ }^{53} \mathrm{~A}$ federal district court ultimately rejected MPHJ's jurisdictional argument and sent the case back to state court. See Vermont v. MPHJ Tech. Investments, LLC, No. 2:13-CV-170, 2014 WL 1494009, at *1 (D. Vt. Apr. 15, 2014).

${ }^{54}$ Int'1 Shoe Co. v. Washington, 326 U.S. 310, 316 (1945). 
sits. ${ }^{55}$ And the Federal Circuit has held that a patent holder who merely sends ceaseand-desist letters into a state does not create the required minimum contacts with that state. ${ }^{56}$ This rule enables litigants such as MPHJ to argue that the act of sending demand letters into Vermont is not sufficient to allow a court sitting in Vermont-state or federal - to exercise jurisdiction over it. ${ }^{57}$ Under MPHJ's reading of the Federal Circuit's case law, which is not unreasonable, any litigant who wishes to challenge its demand letter practices must travel to MPHJ's home state of Texas. Congress, however, has the power to authorize the federal courts to exercise personal jurisdiction on a nationwide basis. ${ }^{58}$ Thus, a federal statute on unfair or deceptive patent demand letters could ensure that a patent holder who blankets the country with letters could be sued in any federal district court in the United States.

Assuming Congress chooses to adopt a federal statute regulating demand letters, what conduct, exactly, should it outlaw? Setting aside for the moment the constitutional constraints discussed above, ${ }^{59}$ the concept of "bad faith" should, in my view, be at the core of the statute. As discussed, a long line of pre-Federal Circuit case law provides substantial guidance to courts in making bad faith determinations.

55 See FED. R. CIV. P. 4(k)(1)(A).

${ }_{56}$ See, e.g., Red Wing Shoe Co. v. Hockerson-Halberstadt, Inc., 148 F.3d 1355, 1361 (Fed. Cir. 1998); see also Megan M. La Belle, Patent Litigation, Personal Jurisdiction, and the Public Good, 18 GeO. MASON L. REV. 43, 47-48 (2010) (critiquing this line of cases).

${ }^{57}$ See Defendant MPHJ Tech. Investments, LLC's Motion to Dismiss at 6-13, Vermont v. MPHJ Tech. Investments, LLC, No. 2:13-CV-170 (D. Vt. filed Sept. 17, 2013).

58 See FED. R. CIV. P. 4(k)(1)(C).

${ }^{59}$ See supra Part III. 
Because of that already-existing case law, I would argue that there is no need for the statute to define bad faith in great detail. A long list of statutory factors, or a complicated statutory definition, would obscure the basic, equitable purpose of the bad faith inquiry. ${ }^{60}$

\section{Conclusion}

Thank you again for inviting me to testify. In my statement, I have sought to highlight that patent holders might currently enjoy an unduly broad immunity from civil liability for their enforcement conduct. Although this immunity could limit the power of Congress to take action against those who abuse the patent system, I hope this hearing will encourage further discussion, both in Congress and in the courts, about the proper scope of protection for patent holders and about whether the states or the federal government are best situated to solve this important problem. I would be pleased to answer any questions the Committee might have for me.

${ }^{60}$ See Richard A. POSNER, REFLECTIONS ON JUdGING 86-87 (2013) (critiquing multifactor legal tests because they obscure the core purpose of the relevant law). 